\title{
Reflective Students in Solving Linear Programming Related Problems
}

\author{
Nourma Pramestie Wulandari \\ Mathematics Education Study Program \\ Universitas Mataram \\ Mataram, Indonesia
}

\author{
Tabita Wahyu Triutami* \\ Mathematics Education Study Program \\ Universitas Mataram \\ Mataram, Indonesia \\ tabita.triutami@unram.ac.id
}

\author{
Dwi Novitasari \\ Mathematics Education Study Program \\ Universitas Mataram \\ Mataram, Indonesia
}

\author{
Abdur Rahman As'ari \\ Mathematics Education Postgraduate Program \\ Universitas Negeri Malang \\ Malang, Indonesia
}

\author{
Dwiyana Dwiyana \\ Mathematics Education Postgraduate Program \\ Universitas Negeri Malang \\ Malang, Indonesia
}

\begin{abstract}
This descriptive study aims to describe how reflective students solving the linear programming related problems. The data were gathered from cognitive style test called Matching Familiar Figure Test (MFFT), linear programming problem solving test and interview. The participants were 22 students in a senior high school located in Pangkalan Banteng, Indonesia. From the MFFT test, it was found that 7 students were having reflective cognitive style, 8 students were having impulsive cognitive style, 4 students were having fast accurate cognitive style and 3 students were having slow inaccurate cognitive style. From those, two students with reflective cognitive styles were chosen as the subject of the study. The data were analyzed qualitatively using descriptive method. The results showed that the reflective students start to solve the problem in Understanding the Problem step by gathering information served in table. Devising a Plan step was done by explaining the steps will be executed, translating problem to the mathematical models and identify the problems to determine the objective function. Carrying Out the Plan step was done by selecting points to draw the graph, area of solution, calculating the intersection point, testing the objective function in each vertex and concluding the optimum value. Looking back was done by checking each step they performed previously.
\end{abstract}

Keywords-cognitive style, problem solving, linear programming, reflective students

\section{INTRODUCTION}

Mathematics teaching and learning should enforce students' curiosity to gather, arrange and use the information to construct a valid conclusion [1]. It will enable the students to be an effective problem solver. The students' problemsolving abilities should not be limited only in mathematics text book, but also in daily life and its application in other knowledges related problems.

In line with its importance, problem solving is recommended as one of the core skills that should be experienced in mathematics classroom, together with mathematical reasoning and proof, communication, connection and representation [2]. To embed the problemsolving as an activity in the classroom, teacher should remember that every students might come with different strategies, techniques or methods [3]. It is happened due to students' difference cognitive style that influence their information gathering and problem-solving [4].
Cognitive style is individual characteristics in gathering, organizing and applying information to solve a problem [5]. It can be seen in how they receive, analyze and response certain cognitive action. Cognitive style is a control process or effort of individual to consciously organize data [6]. It also the various style of sensing, recalling, thinking, differentiating and precepting information to create something new [7]. Understanding the students' cognitive knowledge will support them in achieving the optimum results in learning.

There are two types of cognitive style based on the time needed in responding a stimulus, i.e. reflective and impulsive cognitive styles. The students who need quite long time but got the answer correctly is considered as reflective, while the one with shorter time but tend to make mistakes in the process is called impulsive [7] \& [8].

To adjust the lesson plan and activities with the students' needs, it is necessary for teacher to understand the students' cognitive style. For instance, the previous studies found that the reflective students were able to retelling the information given in the problem and correctly figure out what is asked [9] \& [10]. In addition, the reflective students are good decision maker and able to choose the reasonable arguments. They also reflected on their works after solving the problem, to recheck the possibilities in making mistakes. Notwithstanding, the overall process were done in a quite long time.

The present study will focus on describing the reflective students' problem-solving process in linear programming problem. There are five steps in problem-solving employed in this study [11]. First, understanding the problem, by identifying the information given in the problem and representing the data using table or picture. Second, devising a plan, by evaluating the data, writing mathematical expression and choosing the appropriate strategy. Third, carrying out the plan by performing mathematical skills and concepts. Fourth, looking back, by evaluating the results and connecting it to the original question, checking other possible strategies to solve the problem and examining the correctness of steps. These steps enable students to solve mathematical problem and help teacher to check the students' works [12]. 


\section{METHODS}

To gain the data related to the reflective students' problem-solving abilities, the study was conducted using descriptive method. The subjects were 22 students of twelfth grade students in Pangkalan Banteng, Indonesia. The data were gathered from students' written work in solving Matching Familiar Figure Test (MFFT) and linear programming tests, supported by their explanation during interview. The data were analyzed qualitatively.

The students were assigned first to work on a valid MFFT test [13]. MFFT test consists of 13 questions, each with 1 standard picture and 8 other variations. The students were asked to choose one from 8 variations, which one is the same picture as the standard. The median time in solving the test was 8.38 minutes.

Analyzing the responses, the participants were categorized in four groups, i.e. reflective ( 7 students), impulsive (8 students), fast-accurate (3 students) and slow inaccurate (4 students). From this result, 2 students from reflective groups were selected by the recommendation of the teacher based on their communication skills. Those 2 students, $\mathrm{A}$ and $\mathrm{Y}$, were continued to the next test in solving linear programming problems (written) and the interview (verbally) to evaluate their process.

\section{RESULT AND DISCUSSION}

As is mentioned previously, two students called A and Y were selected to follow the problem-solving test in linear programming. In the following discussion we will explain the students' answers and its relation toward their cognitive style. Consider the following Fig.1. and Fig.2.

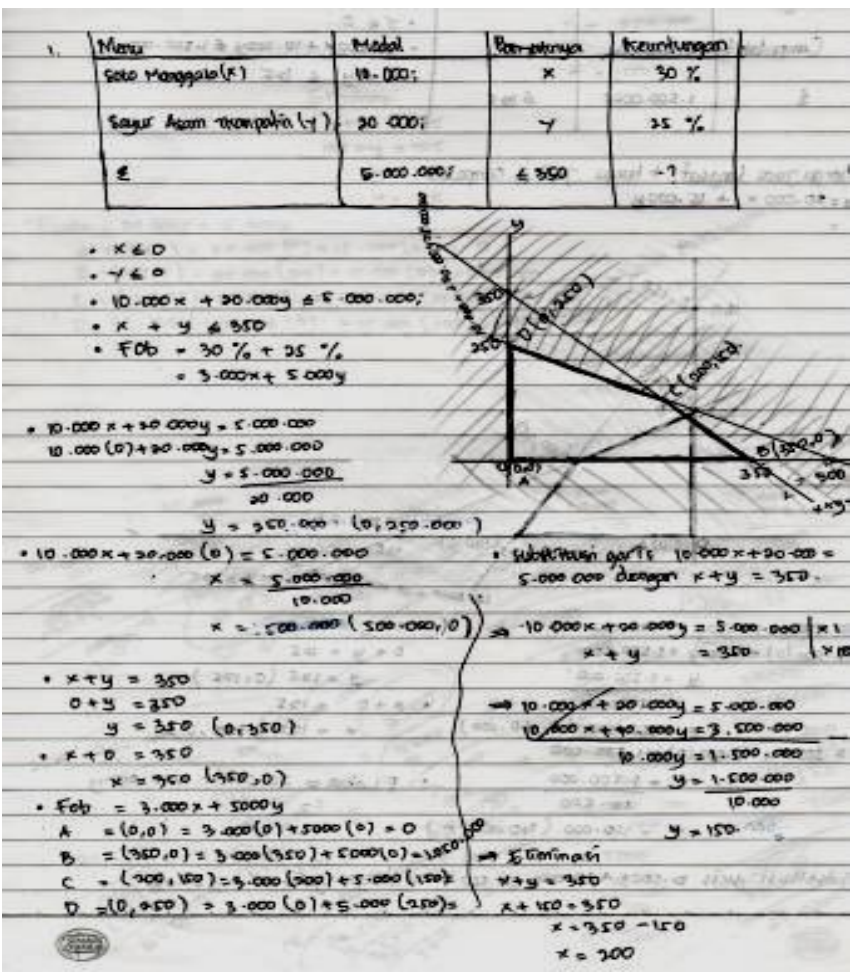

Fig. 1. Solution of Subject A
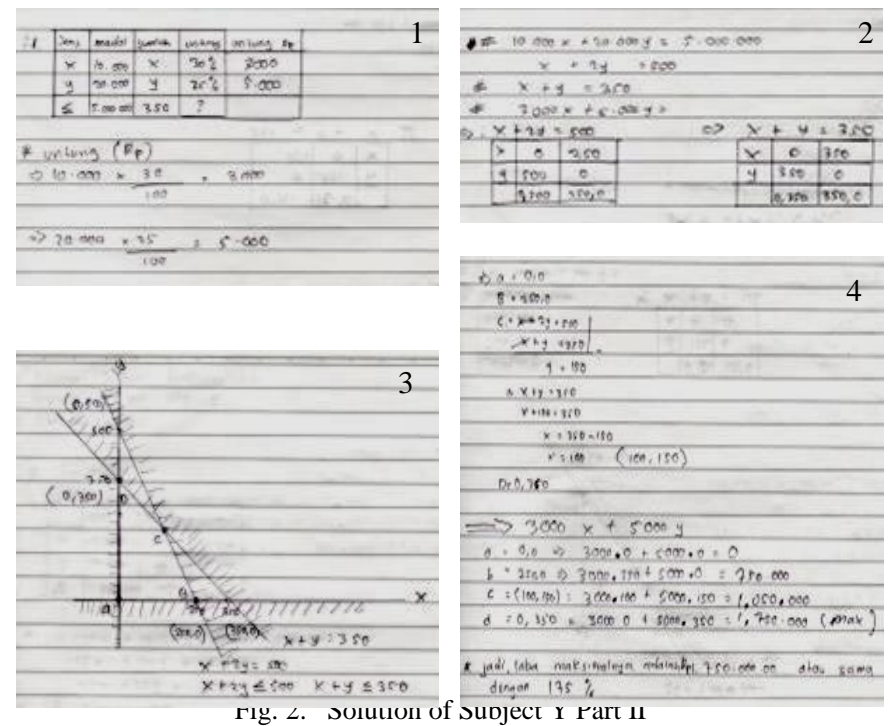

From the students' answers it can be seen that the students started by understanding the problem. It was done simultaneously from gathering information to writing the representation of the problem. Both students did this step completely. The translating process done by applying the information into the mathematical form they familiar with [14]. This is an important step as it will be the first foundation to find the strategy [15].

In Devising a Plan, the students modify the information given in the problem. It is confirmed by previous study which revealed that modification is done based on students' initial knowledge and its connection to solve the problem [16]. In this study, the students modify the percentage form given in the problem into integers and determine the profit for each menu. The modification was presented into table and mathematical model. It confirmed the previous study that reflective students tend to formulate the problem into mathematical model and graphical illustration to plan and detect the steps to solve the problem [17].

During the interview, the subjects also explain that they created the table from the given information in the problem and determined the coordinate points to draw the graph. Afterwards, the students drew the graph and determined the area of the solution. Lastly, the intersection points were determined and it was tested to determine the maximum value asked in the problem.

In the Carrying out the Plan, the students determined the coordinate points based on the boundaries given in the problem that were transformed into linear equation with two variables form. The students' found the coordinate points algebraically by using the mixed method from elimination and substitution. Besides algebraic approach, there are another possible way to solve the problem that usually introduced in senior high school, namely by using geometry approach [18]. The students' ability in choosing the right method showed their mathematical connection abilities [19].

In the phase of choosing coordinate points, student $\mathrm{Y}$ were not exactly pointed the right one. Hence, the graph was incorrect. Also, student Y did mistake when determine the value for $x$ in the intersection point, even though the other procedures were correctly handled. On the other hand, the 
student A was incorrectly mentioned the name of method used to solve the problem (elimination/substitution), but correctly determined the intersection point of two lines. Overall, the reflective students in this study were able to execute the plan, write the calculation and formulate answer in their own words. The result confirmed the previous study that even though some minor errors occurred, the reflective students were able to solve the problem [10].

In the end, the Looking Back phase was done in each other previous step. However, not all coordinate points especially those in the corners were tested by student A. Also, student A did determine what is the maximum profit and what is the percentage of it. It was due to the lack time as student A needed a longer time to reflect on the problem. During the interview, student A was correctly explaining the strategy to solve the last step of the problem.

Student $Y$ found the final answer of maximum profit, but incorrectly as error in calculation of the value of $x$ was occurred. Due to the time limitation, the percentage of the profit was not evaluated. Here, we observed that the time management was difficult for the reflective students. This characteristic in line with the previous study that the reflective students need longer time to solve the problem since they need to re-read the problem repeatedly before solving it [20]. They also tend to check their work frequently to ensure they do not make mistake.

Awareness of reflective students' condition in solving the problem, it is necessary for the teachers to provide meaningful support for students. It can be done by inserting scaffolding and guiding trough questions during the learning activities. Some previous studies showed how those supports helped the students to better performing in mathematical classroom [21], [22] \& [23].

\section{CONCLUSION}

Based on the result of the study, the problem-solving process of the reflective students were following all the steps of Polya. They started by understanding the problem organizing the data, making plan, explain their ideas (during interview), translating the problems into mathematical expression, making visual support or choosing the right mathematical model to support them until they got the result and check the correctness of the process and final answer.

In this study, even though the students were able to find the optimum score asked in the problem, they cannot determine the percentage of profits, due to time limitation. This study confirmed that it takes longer time to a reflective student in solving a mathematical problem. Hence, teacher may support the process by providing scaffolding or guidance questions written in the worksheet or verbally.

\section{REFERENCES}

[1] A. R. As'ari, "Mengerjakan soal latihan matematika: hanya agar terjawab dengan cepat dan akurat?," no. March, 2015, doi: 10.13140/2.1.3027.6649.

[2] NCTM, Principles and Standards for School Mathematics. Virginia: The NCTM, Inc, 2000

[3] G. Ahghar, "Effect of problem-solving skills education on autoregulation learning of high school students in Tehran," Procedia - Soc.
Behav. Sci., vol. 69, no. Iceepsy, pp. 688-694, 2012, doi: 10.1016/j.sbspro.2012.11.462.

[4] H. Alamolhodaei, "Convergent / divergent cognitive styles and mathematical problem solving," J. Sci. Math. Educ. Southeast Asia, vol. XXIV, no. 2, pp. 102-117, 2010.

[5] H. Munawaroh and B. Sugiarto, "Profil metakognisi siswa dalam memecahkan masalah kelarutan dan hasil kali kelarutan berdasarkan gaya kognitif reflektif dan impulsif," Unesa J. Chem. Educ., vol. 3, no. 3, pp. 193-200, 2014

[6] S. W. Bassey, G. Umoren, and L. A. Udida, "Cognitive styles , secondary school students ' attitude and academic performance in chemistry in Akwa Ibom State - Nigeria .," Episteme Conf., pp. 1-8, 2009.

[7] J. Kagan, "Reflection-impulsivity: the generality and dynamics of conceptual tempo," J. Abnorm. Psychol., vol. 71, no. 1, pp. 17-24, 1966.

[8] J. W. Santrock, Psikologi pendidikan edisi 3. Jakarta: Salemba Humanika.

[9] P. R. Ningsih, "Profil berpikir kritis siswa SMP dalam menyelesaikan masalah matematika berdasarkan gaya kognitif," vol. II, no. 2, pp. 120 127,2012

[10]I. M. Azhil, A. Ernawati, and M. Lutfianto, "Profil pemecahan masalah matematika siswa ditinjau dari gaya kognitif reflektif dan impulsif," $J$. Rev. Pembelajaran Mat., vol. 2, no. 1, pp. 60-68, 2017, doi: 10.15642/jrpm.2017.2.1.60-68.

[11]G. Polya, How to solve it: a new aspect of mathematical method, 2nd ed. New Jersey: Pricenton University Press, 1973

[12] T. Zainuri, A. R. As'ari, and I. M. Sulandra, "Analisis kemampuan siswa dengan gaya kognitif field independent dalam memecahkan masalah matematika berdasarkan langkah-langkah Polya," in Prosiding Seminar Nasional Tahun 2016: Pengembangan Profesionalisme Guru dan Dosen Indonesia, 2016.

[13] W. Warli, "Kreativitas siswa SMP yang bergaya kognitif reflektif atau impulsif dalam memecahkan masalah geometri," J. Pendidik. dan Pembelajaran Univ. Negeri Malang, vol. 20, no. 2, pp. 190-201, 2013.

[14]C. Christou, N. Mousoulides, M. Pittalis, D. Pitta-Pantazi, and B. Sriraman, "An empirical taxonomy of problem posing processes," ZDM - Int. J. Math. Educ., vol. 37, no. 3, pp. 149-158, 2005, doi: 10.1007/s11858-005-0004-6.

[15]Y. D. Lestari, "Metakognisi siswa dalam memecahkan masalah matematika berdasarkan gaya kognitif," MATHEdunesa, vol. 1, no. 1, 2012.

[16]P. H. Chua, K. Y. Wong, and M. E. R. G. of Australasia, "Characteristics of Problem Posing of Grade 9 Students on Geometric Tasks," Math. Educ. Res. Gr. Australas., p. 35, 2012.

[17]A. Nasriadi, "Berpikir reflektif siswa SMP dalam memecahkan masalah matematika ditinjau dari perbedaan gaya kognitif," Numer. J., vol. III, no. 1, pp. 15-26, 2016, doi: 10.1017/CBO9781107415324.004.

[18]D. E. Boye, E. Kavanaugh, and L. G. Williams, Intermediate algebra. Boston: PWS-Kent Publishing Company, 1991.

[19]R. L. Solso, O. H. Maclin, and K. Maclin, Cognitive psychology 8th edition. Harlow: Pearson Education Limited, 2014.

[20]M. Fadiana, "Perbedaan kemampuan menyelesaikan soal cerita antara siswa bergaya kognitif reflektif dan impulsif," J. Res. Adv. Math. Educ., vol. 1, no. 1, pp. 79-89, 2016. 
[21]I. N. Gita and R. A. Apsari, "Scaffolding in problem based learning to increase students' achievements in linear algebra," J. Phys. Conf. Ser., vol. 1040, no. 1, 2018, doi: 10.1088/1742-6596/1040/1/012024.

[22]R. D. Vale, "The value of asking questions," Mol. Biol. Cell, vol. 24, no. 6, pp. 680-682, 2013, doi: 10.1091/mbc.E12-09-0660.
[23]M. Miyazaki, T. Fujita, and K. Jones, "Flow-chart proofs with open problems as scaffolds for learning about geometrical proofs," ZDM Math. Educ., vol. 47, no. 7, pp. 1211-1224, 2015, doi: 10.1007/s11858015-0712-5. 